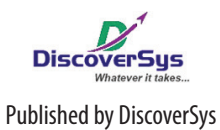

Published by DiscoverSys

\section{Hormonal Contraceptive Use and History of Sexually Transmitted Infection as Risk Factors of the Pre-Cancerous Cervical Lesions}

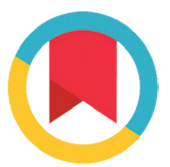

CrossMark

\section{ABSTRACT}

Background and purpose: Screening for pre-cancerous cervical lesions is already being implemented in Bali. This study aims to determine hormonal contraceptives and STI history as risk factors of pre-cancerous cervical lesions.

Methods: A case-control study was conducted involving 76 women of childbearing age diagnosed with pre-cancerous cervical lesions who screened at two health centers in Denpasar Bali from January to March 2015. Control was 76 women of childbearing age with no pre-cancerous cervical lesions who screened at the same period. Consecutive sampling was used to select cases and controls. Data were collected through interview using questionnaires and analyzed using logistic regression to calculate adjusted odd ratio of each risk factor. Results: Multivariate analysis indicated that the use of hormonal contraceptives over $\geq 5$ or $<5$ years increase risk of pre-cancerous cervical lesions with $\mathrm{OR}=10,7(95 \% \mathrm{Cl}: 1,04-108,17)$ and $\mathrm{OR}=3,0$ (95\%Cl: 1,16-7,84) compared to those who were not using hormonal contraception. History of sexually transmitted infections also increases risk of pre-cancerous cervical lesions with $0 \mathrm{R}=9,7(95 \% \mathrm{Cl}: 3,83-24,18)$. Conclusion: The use of hormonal contraceptives and history of sexual transmitted infections increased risks of pre-cancerous cervical lesions.

Keywords: pre-cancerous cervical lesions, hormonal contraceptives, STI history

Cite This Article: Parwati, N.M., Putra, I.W.G.A.E., Karmaya, I.N.M. 2015. Hormonal Contraceptive Use and History of Sexually Transmitted Infection as Risk Factors of the Pre-Cancerous Cervical Lesions. Public Health and Preventive Medicine Archive 3(2): 138-142. D0l:10.15562/phpma.v3i2.105

\title{
Kontrasepsi Hormonal dan Riwayat Infeksi Menular Seksual sebagai Faktor Risiko Lesi Pra-Kanker Leher Rahim
}

Latar belakang dan tujuan: Saat ini pemeriksaan dengan IVA dan pap smear untuk skrining lesi pra-kanker leher rahim telah dilaksanakan di Provinsi Bali. Penelitian ini bertujuan untuk mengetahui kontrasepsi hormonal dan riwayat IMS sebagai faktor risiko lesi pra-kanker leher rahim.

Metode: Rancangan penelitian adalah kasus-kontrol dengan sampel kasus sebanyak 76 wanita PUS yang didiagnosis positif lesi pra-kanker dengan pemeriksaan IVA dan konfirmasi pemeriksaan pap smear di dua puskesmas di Denpasar Bali dari Bulan Januari sampai Maret 2015. Kontrol sebanyak 76 wanita PUS dipilih dari mereka yang negatif pada

${ }^{1}$ Bali Health Office, ${ }^{2}$ Public Health Postgraduate Program Udayana University, ${ }^{3}$ School of Public Health Faculty of Medicine Udayana University, ${ }^{4}$ Department of Anatomy School of Medicine Faculty of Medicine Udayana University

${ }^{*}$ Correspondence to:

Ni Made Parwati, Bali Health Office, Public Health Postgraduate Program Udayana University parwati.made@yahoo.com periode yang sama. Sampel kasus dan kontrol dipilih secara consecutive. Data tentang faktor risiko dikumpulkan melalui wawancara dengan mempergunakan kuesioner. Analisis data dilakukan dengan metode regresi logistik untuk mendapatkan adjusted odd ratio masing-masing faktor risiko.

Hasil: Analisis multivariat menunjukkan bahwa penggunaan kontrasepsi hormonal ( $>5$ tahun maupun $<5$ tahun) meningkatkan risiko lesi pra-kanker leher rahim dibandingkan yang tidak menggunakan kontrasepsi hormonal masing-masing dengan $O R=10,7 \quad(95 \% \mathrm{Cl}: 1,04-108,17)$ dan $0 \mathrm{R}=3,0 \quad(95 \% \mathrm{Cl}: 1,16-7,84)$. Riwayat IMS juga meningkatkan risiko lesi pra-kanker leher rahim dengan $0 \mathrm{R}=9,7(95 \% \mathrm{Cl}: 3,83-24,18)$.

Simpulan: Pemakaian kontrasepsi hormonal dan riwayat IMS meningkatkan risiko lesi pra-kanker leher rahim.

Kata kunci: lesi pra-kanker leher rahim, kontrasepsi hormonal, riwayat IMS

Kutip artikel ini: Parwati, N.M., Putra, I.W.G.A.E., Karmaya, I.N.M. 2015. Kontrasepsi Hormonal dan Riwayat Infeksi Menular Seksual sebagai Faktor Risiko Lesi Pra-Kanker Leher Rahim. Public Health and Preventive Medicine Archive 3(2): 138-142. D0I:10.15562/phpma.v3i2.105

\section{PENDAHULUAN}

Kanker leher rahim merupakan penyakit keganasan yang didahului dengan kondisi lesi pra-kanker leher rahim yaitu adanya displasia/neoplasia intraepitel serviks (NIS). Kejadian kanker leher rahim terus 
mengalami peningkatan dan mencapai 530.232 kasus setiap tahunnya dan merupakan penyebab kematian tertinggi pada wanita usia subur di dunia. ${ }^{1}$ Di Indonesia dilaporkan sekitar 15.000 kasus baru dengan kematian sebanyak 7.500 kasus per tahun. ${ }^{2}$ Di Bali insiden kanker leher rahim diperkirakan 150 per 100.000 penduduk atau sekitar 5000 orang pada tahun 2011 dengan angka kematian sebesar 82 per 100.000 penduduk. ${ }^{3}$ Penyakit ini dapat sembuh jika dideteksi pada stadium awal yaitu dalam tahap lesi pra-kanker. ${ }^{4}$

Infeksi Human Papilloma Virus (HPV) yang ditularkan melalui hubungan seksual adalah salah satu faktor penyebab keganasan pada leher rahim. Infeksi Menular Seksual (IMS) lainnya tanpa pengobatan yang adekuat diduga mempercepat berkembangnya HPV. ${ }^{5}$ Faktor yang juga dilaporkan meningkatkan risiko kanker leher rahim adalah penggunaan kontrasepsi hormonal, akan tetapi beberapa penelitian menunjukkan hasil yang berbeda-beda. ${ }^{6}$ Faktor lainnya adalah: wanita yang berumur 30-50 tahun dan masih aktif berhubungan seksual, umur pertama kali berhubungan seksual, paritas, gizi, wanita perokok aktif maupun pasif. ${ }^{7,8}$

Penelitian terkait risiko penggunaan kontrasepsi hormonal dan riwayat IMS dengan kejadian lesi pra-kanker leher rahim belum pernah dilakukan di Kota Denpasar. Penelitian ini dilakukan di Puskesmas I Denpasar Utara dan Puskesmas II Denpasar Selatan dengan pertimbangan Puskesmas I Denpasar Utara memiliki PUS dengan akseptor hormonal tertinggi di Denpasar pada tahun 2013 yaitu 40,3\%. Puskesmas II Denpasar Selatan merupakan puskesmas dengan kunjungan IMS melebihi puskesmas lainnya yaitu tahun 2012 sebesar $15 \%$ dan $17 \%$ pada tahun $2013 .{ }^{9}$

Selama ini skrining lesi pra-kanker leher rahim dilakukan dengan pemeriksaan IVA, tetapi memberikan hasil yang subyektif dan berpotensi untuk terjadinya hasil positif palsu. ${ }^{2}$ Dalam upaya mengurangi hasil positif palsu pada temuan IVA, dapat digunakan dengan menggunakan penapisan dua tahap yaitu dengan metode IVA dan pap smear. ${ }^{10}$

Penelitian ini dilakukan untuk mengetahui besarnya risiko penggunaan kontrasepsi hormonal dan riwayat infeksi menular seksual terhadap kejadian lesi pra-kanker leher rahim berdasarkan pemeriksaan dua tahap menggunakan metode IVA dan pap smear pada wanita pasangan usia subur (PUS).

\section{METODE}

Rancangan penelitian adalah case control dengan sampel kasus sebanyak 76 wanita PUS yang didiagnosis positif lesi pra-kanker dengan pemeriksaan IVA dan konfirmasi pemeriksaan pap smear di dua puskesmas, yaitu Puskesmas I Denpasar Utara dan Puskesmas II Denpasar Selatan dari Bulan Januari sampai Maret 2015. Kontrol sebanyak 76 wanita PUS dipilih dari mereka yang negatif pada periode yang sama. Sampel kasus dan kontrol dipilih secara consecutive.

Variabel terikat dalam penelitian ini adalah lesi pra-kanker leher rahim, sedangkan kontrasepsi hormonal dan riwayat IMS sebagai variabel bebas. Umur, paritas, paparan asap rokok, status gizi, perilaku seksual dan hubungan seksual usia dini sebagai variabel perancu. Data tentang variablevariabel ini dikumpulkan dengan mempergunakan kuesioner. Analisis data dilakukan secara bivariat dan multivariat. Analisis bivariat untuk mengetahui kemiripan karakteristik kelompok kasus dan kontrol dan untuk menghitung crude odd ratio (OR). Analisis multivariat dilakukan dengan metode regresi logistik untuk menghitung adjusted OR. Penelitian ini telah dinyatakan laik etik oleh Komisi Etik Penelitian Fakultas Kedokteran Univeritas Udayana/Rumah Sakit Umum Pusat Sanglah Denpasar.

\section{HASIL}

Selama penelitian 152 orang wanita PUS yang memenuhi kriteria inklusi dan kriteria eksklusi melakukan pemeriksaan lesi pra-kanker menggunakan metode IVA dan jika hasil IVA positif dilanjutkan dengan pemeriksaan pap smear. Sampel dengan hasil pemeriksaan IVA dan pap smear menunjukkan lesi pra-kanker dijadikan kelompok kasus. Wanita PUS dengan hasil IVA negatif atau pap smear negatif (salah satu negatif) dikategorikan sebagai kontrol. Pada Tabel 1 disajikan perbandingan karakteristik antara kelompok kasus dan kontrol. Terlihat bahwa tidak ada perbedaan yang bermakna berdasarkan variabel pendidikan, pekerjaan, frekuensi pernikahan dan paritas $(p>0,05)$ tetapi dijumpai adanya perbedaan berdasarkan umur. Pada kelompok kontrol proporsi subjek yang berumur $\leq 35$ tahun sebesar 69,7\% sedangkan pada kelompok kasus sebesar $50,0 \%(\mathrm{p}=0,013)$.

Hasil analisis bivariat menunjukkan bahwa terdapat enam variabel yang berperan meningkatkan risiko lesi pra-kanker leher rahim yaitu kontrasepsi hormonal, riwayat IMS, umur $>35$ tahun, paparan asap rokok, perilaku seksual berisiko dan hubungan seksual usia dini, seperti disajikan dalam Tabel 2. Dari analisis bivariat ada tujuh variabel yang memiliki nlai $\mathrm{p}<0,25$, dan selanjutnya dilakukan analisis multivariat yang hasilnya disajikan pada Tabel 3 . 
Tabel 1 Komparasi karaktersitik responden antara kasus dan kontrol

\begin{tabular}{lccc}
\hline Karakteristik & $\begin{array}{c}\text { Kasus } \\
\mathbf{n}(\%)\end{array}$ & $\begin{array}{c}\text { Kontrol } \\
\mathbf{n}(\%)\end{array}$ & Nilai p* \\
\hline $\begin{array}{l}\text { Umur } \\
\quad 35 \text { tahun }\end{array}$ & $38(50,0)$ & $53(69,7)$ & 0,013 \\
$\quad>35$ tahun & $38(50,0)$ & $23(30,3)$ & 0,717 \\
$\begin{array}{l}\text { Pendidikan } \\
\quad<\text { SMP }\end{array}$ & $56(73,7)$ & $54(71,1)$ & 0,189 \\
$>$ SMA & $20(26,3)$ & $22(28,9)$ & \\
$\begin{array}{l}\text { Pekerjaan } \\
\text { Ibu rumah tangga }\end{array}$ & $28(36,8)$ & $36(47,4)$ & 0,560 \\
Selain ibu rumah tangga & $48(63,2)$ & $40(52,6)$ & \\
Frekuensi pernikahan & $74(97,4)$ & $75(98,7)$ & $1(1,3)$ \\
1 kali & $2(2,6)$ & & 0,309 \\
$>1$ kali & & $73(96,1)$ & \\
Paritas & $70(92,1)$ & $3(3,9)$ & \\
$<3$ & $6(7,9)$ & & \\
$>4$ & & & \\
\hline
\end{tabular}

*) $\mathrm{X}^{2}$ test

Tabel 2 Crude OR antara kontrasepsi hormonal, riwayat IMS, umur, paparan asap rokok, paritas, status gizi, perilaku seksual dan hubungan seksual usia dini terhadap lesi pra-kanker leher rahim

\begin{tabular}{|c|c|c|c|c|c|}
\hline Variabel & $\begin{array}{l}\text { Kasus } \\
\text { n (\%) }\end{array}$ & $\begin{array}{c}\text { Kontrol } \\
\text { n (\%) }\end{array}$ & Crude OR & $95 \% \mathrm{Cl}$ & Nilai $\mathbf{p}^{*}$ \\
\hline \multicolumn{6}{|c|}{ Kontrasepsi hormonal } \\
\hline Tidak & $44(47,9)$ & $56(73,7)$ & & & \\
\hline $\mathrm{Ya}<5$ tahun & $25(32,9)$ & $19(25,0)$ & 1,7 & $0,81-3,42$ & 0,158 \\
\hline Ya $>5$ tahun & $7(9,2)$ & $1(1,3)$ & 8,9 & $1,05-75,13$ & 0,044 \\
\hline \multicolumn{6}{|l|}{ Riwayat IMS } \\
\hline Tidak & $32(42,1)$ & $63(82,9)$ & & & \\
\hline $\mathrm{Ya}$ & $44(57,9)$ & $13(17,1)$ & 6,6 & $2,97-15,32$ & 0,001 \\
\hline \multicolumn{6}{|l|}{ Umur } \\
\hline$<35$ tahun & $38(50,5)$ & $53(69,7)$ & & & \\
\hline$>35$ tahun & $38(50,5)$ & $23(30,3)$ & 2,3 & $1,12-4,73$ & 0,013 \\
\hline \multicolumn{6}{|c|}{ Paparan asap rokok } \\
\hline Tidak terpapar & $38(50,0)$ & $50(65,8)$ & & & \\
\hline Terpapar & $38(50,0)$ & $26(34,2)$ & 1,9 & $0,91-3,89$ & 0,048 \\
\hline \multicolumn{6}{|l|}{ Paritas } \\
\hline$<3$ & $70(92,1)$ & $73(96,1)$ & & & \\
\hline$>4$ & $6(6,9)$ & $3(4,0)$ & 2,1 & $0,42-13,32$ & 0,302 \\
\hline \multicolumn{6}{|l|}{ Status gizi } \\
\hline Normal & $71(93,4)$ & $75(98,7)$ & & & \\
\hline Kurang & $5(6,6)$ & $1(1,3)$ & 5,3 & $0,56-253,03$ & 0,096 \\
\hline \multicolumn{6}{|l|}{ Perilaku seksual } \\
\hline Tidak berisiko & $41(54,0)$ & $66(86,8)$ & & & \\
\hline Berisiko & $35(46,0)$ & $10(13,2)$ & 5,6 & $2,38-14,02$ & 0,001 \\
\hline \multicolumn{6}{|c|}{ Hubungan seksual usia dini } \\
\hline Tidak & $23(27,6)$ & $33(43,4)$ & & & \\
\hline $\mathrm{Ya}$ & $53(72,4)$ & $43(56,6)$ & 2 & $0,96-4,19$ & 0,042 \\
\hline
\end{tabular}


Tabel 3 Adjusted OR antara kontrasepsi hormonal, riwayat IMS, umur, hubungan seksual usia dini dan perilaku seksual terhadap lesi pra-kanker leher rahim

\begin{tabular}{|c|c|c|c|c|}
\hline \multirow[b]{2}{*}{ Variabel } & \multirow[b]{2}{*}{ Adjusted OR } & \multicolumn{2}{|c|}{$95 \% \mathrm{Cl}$} & \multirow[b]{2}{*}{ Nilai p } \\
\hline & & Lower & Upper & \\
\hline \multicolumn{5}{|l|}{ Menggunakan kontrasepsi hormonal } \\
\hline$>5$ tahun & 10,7 & 1,04 & 108,17 & 0,045 \\
\hline$<5$ tahun & 3,0 & 1,16 & 7,84 & 0,023 \\
\hline Ada riwayat IMS & 9,7 & 3,83 & 24,18 & 0,001 \\
\hline Umur $>35$ tahun & 4,0 & 1,63 & 9,63 & 0,002 \\
\hline Pertama kali berhubungan seksual pada usia dini & 3,3 & 1,31 & 8,06 & 0,011 \\
\hline Perilaku seksual berisiko & 4,6 & 1,84 & 11,43 & 0,001 \\
\hline
\end{tabular}

Hasil analisis multivariat (Tabel 3) menunjukkan bahwa penggunaan kontrasepsi hormonal $(>5$ tahun maupun $<5$ tahun) meningkatkan risiko lesi pra-kanker leher rahim dibandingkan yang tidak menggunakan kontrasepsi hormonal masing-masing dengan $\mathrm{OR}=10,7$ (95\%CI: $1,04-$ 108,17) dan OR=3,0 (95\%CI: 1,16-7,84). Riwayat IMS juga meningkatkan risiko lesi pra-kanker leher rahim dengan $\mathrm{OR}=9,7$ (95\%CI: 3,83-24,18). Pada Tabel 3 juga terlihat bahwa umur di atas 35 tahun, pertama kali berhubungan seksual pada usia dini dan perilaku seksual berisiko meningkatkan risiko terjadinya lesi pra-kanker leher rahim, masingmasing dengan $\mathrm{OR}=4,0 \quad$ (95\% CI: 1,63-9,63); $\mathrm{OR}=3,3(95 \% \mathrm{CI}: 1,31-8,06)$ dan $\mathrm{OR}=4,6(95 \% \mathrm{CI}$ : $1,84-11,43)$.

\section{DISKUSI}

Penelitian ini menunjukkan bahwa penggunaan kontrasepsi hormonal dan riwayat IMS meningkatlan risiko terjadinya lesi pra-kanker leher rahim. Wanita PUS yang menggunakan kontrasepsi hormonal $>5$ tahun memiliki risiko 10,7 kali lebih tinggi mengalami lesi pra-kanker leher rahim dibandingkan dengan yang tidak menggunakan kontrasepsi hormonal, dan penggunaan $<5$ tahun meningkatkan risiko sebesar 3,0 kali lebih tinggi dibandingkan dengan wanita PUS yang tidak menggunakan kontrasepsi hormonal. Hasil ini sesuai dengan hasil penelitian yang dilaporkan oleh Triwahyuningsih tahun 2013 di Jatinegara. ${ }^{11}$ Dalam penelitian ini dilaporkan dengan pemeriksaan satu tahap (tes IVA saja) dijumpai bahwa pemakaian kontrasepsi hormonal (pil) $>4$ tahun meningkatkan risiko menderita lesi pra-kanker leher rahim sebesar 42 kali. Demikian juga hasil penelitan yang dilaporkan oleh Suriani di Kecamatan Payangan Gianyar tahun 2011 dengan pemeriksaan menggunakan metode yang sama (IVA), yang menyatakan kontrasepsi hormonal dapat meningkatkan risiko lesi pra-kanker leher rahim sebesar 2,0 kali (OR=1,99; 95\%CI: 1,24-3,19). ${ }^{12}$

Secara biomedis, fenomena ini kemungkinan karena kontrasepsi hormonal memicu terjadinya perubahan pada epitel leher rahim yang terlihat setelah pemakaian pil kontrasepsi selama 5 tahun berturut-turut. Hal ini diduga akibat estrogen menginduksi onkogenesis secara langsung pada epitel leher rahim. ${ }^{13}$ Andrijono mengemukakan pendapat yang sama bahwa penggunaan kontrasepsi hormonal meningkatkan risiko lesi pra-kanker leher rahim. ${ }^{5}$ Kesimpulan tersebut diperoleh berdasarkan penelitian meta analisis yaitu penggunaan selama 10 tahun dapat meningkatkan risiko sampai dua kali. Sejalan dengan Harahap yang menyatakan mekanisme terjadinya kanker leher rahim adalah pengaruh kontrasepsi hormonal terhadap perubahan epitel kolumnar menjadi epitel skuamosa atau proses eversi. ${ }^{14}$

Dari analisis multivariat diperoleh hasil riwayat IMS 9,7 kali meningkatkan risiko lesi pra-kanker leher rahim dibandingkan dengan wanita PUS yang tidak pernah mengalami IMS. Hasil ini sesuai dengan penelitian Melva tahun 2008 yang dalam penelitiannya menggunakan pemeriksaan IVA menyatakan wanita dengan riwayat penyakit kelamin memiliki risiko yang lebih besar untuk terkena kanker leher rahim dengan $\mathrm{RP}=2,58$ (95\%CI: 1,69-3,76). ${ }^{15}$ Carol et al melaporkan hasil yang serupa, melalui pemeriksaan pap smear pada lima daerah di Amerika pada tahun 2005, ditemukan bahwa wanita dengan riwayat IMS mempunyai risiko 2,6 kali lebih tinggi mengalami lesi pra-kanker leher rahim. ${ }^{16}$ Hasil yang serupa juga dilaporkan oleh Kharsany di Durban bahwa ada hubungan antara infeksi menular seksual dengan lesi pra-kanker leher rahim. ${ }^{17}$ Secara biomedis bisa dijelaskan bahwa IMS kemungkinan berperan sebagai ko-faktor infeksi virus papiloma pada manusia. IMS kemungkinan menyebabkan terjadinya lesi pada leher rahim yang selanjutnya 
mempermudah masuknya virus HPV ke basal membran leher rahim. Selain itu IMS pada wanita kemungkinan juga mempengaruhi daya tahan tubuh dan mempercepat berkembangnya infeksi virus HPV. Sistem imunitas yang tertekan merupakan predisposisi infeksi virus onkogenik. ${ }^{5}$

Implikasi penelitian ini yang berkaitan dengan kebijakan kesehatan masyarakat antara lain meningkatkan cakupan skrining IMS pada wanita yang kemungkinan bisa dilakukan bersama-sama dengan skrining kanker leher rahim dengan IVA atau pap smear. Implikasi lainnya yang berkaitan dengan tata laksana pasien adalah memberikan konseling yang lebih baik kepada wanita tentang pemilihan kontrasepsi.

Penelitian ini hanya dilakukan di suatu populasi yang terbatas, yaitu dua puskesmas di Kota Denpasar. Karena itu hasil penelitian ini tidak bisa digeneralisir ke populasi yang lebih luas.

\section{SIMPULAN}

Pemakaian kontrasepsi hormonal dan riwayat IMS meningkatkan risiko lesi pra-kanker leher rahim. Selain itu umur di atas 35 tahun, pertama kali berhubungan seksual pada usia dini dan perilaku seksual berisiko juga meningkatkan risiko terjadinya lesi pra-kanker leher rahim.

\section{UCAPAN TERIMA KASIH}

Ucapan terima kasih penulis sampaikan kepada semua responden dan semua pihak yang telah membantu pelaksanaan penelitian ini.

\section{DAFTAR PUSTAKA}

1. WHO/ICO. Comprehensive Cervical Cancer Prevention and Control a Healthier Future for Girls and Women: Summary Report update 2013.WHO; 2013.

2. Departemen Kesehatan RI. Skrining Kanker Leher Rahim Dengan Metode IVA. Jakarta: Depkes RI; 2008.
3. Dinas Kesehatan Provinsi Bali. Profil Kesehatan Provinsi Bali Tahun 2013. Denpasar: Dinas Kesehatan Provinsi Bali; 2014

4. Suwiyoga, IK. Beberapa Masalah Pap Smear sebagai Alat Diagnosis Dini Kanker Serviks Di Indonesia. Jurnal Studi Jender Srikandi. 2010 (diakses 14 Juli 2014). Available from URL: http: ojs.unud.ac.id/index.php/srikandi/article/ view/2755.

5. Andrijono. Kanker Serviks. Jakarta: Divisi Onkologi Departemen Obstetri Ginekologi Fakultas Kedokteran Universitas Indonesia; 2009.

6. Rasjidi. Manual Prakanker Serviks. Jakarta: Sagung Seto; 2008.

7. Delia, W. Pembunuh Ganas itu Bernama Kanker Servik. Yogyakarta: Kejora; 2010.

8. Andrijono. Sinopsis Kanker Ginekologi. Jakarta: Divisi Onkologi Departemen Obstetri Ginekologi, Fakultas Kedokteran Universitas Indonesia; 2013.

9. Dinas Kesehatan Kota Denpasar. Profil Kesehatan Kota Denpasar Tahun 2013. Denpasar: Dinas Kesehatan Kota Denpasar; 2014

10. Departemen Kesehatan RI. Skrining Kanker Leher Rahim dengan Metode IVA. Jakarta: Depkes RI; 2008.

11. Triwahuningsih. Faktor Risiko yang Berhubungan dengan Kejadian Lesi Prakanker Leher Rahim dengan Metode IVA di Puskesmas Jatinegara (tesi). Jakarta: Universitas Esa Unggul; 2013.

12. Suriani. Faktor Risiko Lesi Prakanker Leher Rahim pada PUS di Kecamatan Payangan Gianyar (tesis. Denpasar: Universitas Udayana; 2011.

13. Rusmana. Aspek Onkologi Human Papillomavirus. Fakultas Kedokteran, Universitas Kristen Maranatha, JKM 2009;9.

14. Harahap. Neoplasia Intraepitel pada Kanker Serviks (NIS), Pendekatan Ilmiah Pencegahan Kanker Leher Rahim. Jakarta: UI Press; 2006.

15. Melva. Faktor-faktor yang Mempengaruhi Kejadian Kanker Leher Rahim di RSUP Adam Malik (tesis). Sumatera Utara: Universitas Sumatera Utara; 2008.

16. Carol, Jones, et al. Risk Factors for Insitu Cervical Cancer: Results from a Case-Control Study Cancerres. AACR Journals.org. 2005 (cited 2014 August 14). Available from URL: http:// cancerres. Aacr journals.Org site/misc/ terms. xhtml.

17. Kharsany, Hoosen. The Association Between Sexually Transmitted Pathogens and Cervical Intra-epithelial Neoplasia in a Developing Community. Genitourin Med 2002;69:35.

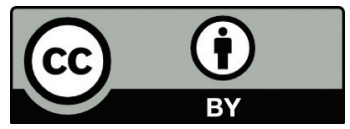

This work is licensed under a Creative Commons Attribution 